\title{
Effects of exogenous tannase enzyme on growth performance, antioxidant status, immune response, gut morphology and intestinal microflora of chicks fed grape pomace
}

\author{
S. K. Ebrahimzadeh ${ }^{1 \#}$, B. Navidshad", P. Farhoomand ${ }^{2}$ \& F. Mirzaei Aghjehgheshlagh ${ }^{1}$ \\ ${ }^{1}$ Department of Animal Science, University of Mohaghegh Ardabili, Ardabil, Iran \\ ${ }^{2}$ Department of Animal Science, Urmia University, Urmia, Iran
}

(Received 4 June 2017; Accepted 13 October 2017; First published online 3 November 2017)

\author{
Copyright resides with the authors in terms of the Creative Commons Attribution 4.0 South African Licence. \\ See: http://creativecommons.org/licenses/by/4.0/za \\ Condition of use: Theuser may copy, distribute, transmit and adapt the work, but must recognise the authors and the South African \\ Journal of Animal Science.
}

\begin{abstract}
An experiment was conducted to study the effects of dietary addition of tannase to feed of chicks including grape pomace (GP) on growth performance, antioxidant status, immune response, blood parameters, gut morphology, intestinal microflora, liver function, and histopathological responses. The experimental diets were i) control (corn and soybean diet) (C); ii) C+10\%GP; iii) C+10\%GP+T1 (500 mg/kg tannase enzyme); and iv) $\mathrm{C}+10 \% \mathrm{GP}+\mathrm{T} 2$ (1000 $\mathrm{mg} / \mathrm{kg}$ tannase enzyme). At 10 days old, the bodyweight (BW) and average daily gain (ADG) of the birds fed the diet supplemented with GP was lower compared with the control group. In contrast with the control, supplementation of diets with $10 \% \mathrm{GP}+1000 \mathrm{mg} / \mathrm{kg}$ tannase elevated superoxide dismutase (SOD) and glutathione peroxidase (GSH-Px) activities and depressed the malondialdehyde (MDA) level in serum. The addition of GP to the chicken diets had a significant impact on the total anti- sheep red blood cells (SRBC) titers and IgG, and IgM antibodies at 21 and 42 days old. The muscularis thickness of the chicken duodenum decreased in the Trial 3 compared with control groups. The inclusion of GP in the chicken diets reduced the concentration of Escherichia coli and increased that of Lactobacillus compared with the control. The results of the present study suggest that the inclusion of up to 10 percent GP in diets did not adversely affect broiler growth performance, and supplementation of tannase improved the antioxidant status and immune responses, and increased the caecal populations of beneficial bacteria in the cecum of broiler chickens.
\end{abstract}

Keywords: Broiler chickens, histopathological responses, glutathione peroxidase, polyphenol, sheep red blood cells

\#Corresponding author: Ebrahimzadeh87@gmail.com

\section{Introduction}

Grapes (Vitis vinifera) are one of the world's largest fruit crops, with an annual production of 77 million metric tons (FAO, 2013). Large quantities of residues are generated in processing grapes. These residues cause problems in economic and ecological terms. Thus, any useful application for these by-products could represent an interesting advance in the maintenance of environmental equilibrium and also an economic evaluation of the raw material (Abarghuei et al., 2010). Grape pomace (GP) is a grape by-product consisting of pressed seeds, skins and stems, and is a rich source of flavonoids, including monomeric phenolic compounds, such as (+)-catechins, (-)-epicatechin, and (-)-epicatechin-3-gallate and dimeric and oligomeric proanthocyanidins (Goni et al., 2007). These polyphenols were considered anti-nutritional factors because their presence in certain ingredients, such as legumes, sunflowers and sorghum, had negative effects on animal nutrition. Probably one of the best-known properties of polyphenolic compounds is their capacity to bind and precipitate proteins. This protein binding capacity is common to most polyphenols due to their high degree of hydroxylation. Low molecular weight phenols are, however, not able to precipitate proteins. Oligomers must contain at least three flavonol subunits to precipitate protein effectively. Additionally, these compounds have the capacity to act as powerful antioxidants by scavenging free radicals and terminating oxidative reactions (Yilmaz \& Toledo, 2004). Various plant polyphenolic compounds have been studied widely because of their antioxidant and antimicrobial activities. Plant extracts that are rich in these polyphenols have been used successfully to protect against diseases caused by organisms such as 
Staphylococcus aureus, Escherichia coli, Candida albicans, and Campylobacter (Tepe et al., 2004). Therefore, GP polyphenols in grape by-products could be used effectively as feed supplements to improve the antioxidant status and immunity of birds. However, the use of such natural antioxidants in animal nutrition could be limited owing to the low bioavailability of grape polyphenols, and might be improved with exogenous enzymes.

Enzyme supplementation is a technique that has had increasing applicability for improving the nutritional characteristics of by-products and is widely used in animal nutrition. A recent in vitro study (Chamorro et al., 2012) reported that the addition of tannase released polyphenols entrapped in GP, increasing its antioxidant activity. Tannase catalyses the hydrolysis of carboxylic ester bonds in the molecules of hydrolysable tannins and gallic acid esters (Lekha \& Lonsane, 1997). Tannase is produced by certain filamentous fungi, mainly Aspergillus, Penicillium, Fusarium and Trichoderma (Libuchi \& Monida Yand Yamada, 1967; Rajakumar \& Nandy, 1983; Kawakubo et al., 1991; Lekha \& Lonsane, 1994; Bajpai \& Patil, 1996; Garcia-Pena et al., 1999) and bacteria (Deschamps et al., 1983; Skene \& Brooker, 1995). Yeasts (Aoki et al., 1976) also produce this enzyme. Most of the work related to tannase has considered production, extraction, purification, and characterization aspects of the enzyme obtained by microbiological methods, using filamentous fungi, mainly Aspergillus, through processes of submerged culture. In general form, fungal tannase is produced by submerged cultures (Lekha \& Lonsane, 1994). It is the chemical structure of polyphenols, rather than the concentration, that determines the rate and extent of absorption and the nature of the metabolites circulating in the plasma. The hydrolysis of complex polyphenols into more digestible phenols might increase the amount of active substances that could be metabolized easily, improving its nutritional value and rendering this by-product more suitable for use as an animal ingredient.

The main objective of this experiment was to study the effects of dietary addition of tannase to the feed of chicks including GP on growth performance, antioxidant status, immune response, blood parameters, gut morphology, intestinal microflora, liver function and histopathological responses.

\section{Materials and Methods}

Red grape pomace (Vitis vinifera) was obtained from TATAO Corporation (Urmia-West Azerbaijan, Iran). The proximate composition of GP was analysed according to procedures described by the Association of Official Analytical Chemists (AOAC, 2000) (Table 1). Total polyphenol content in GP, diet, ileal digesta and excreta were determined after extraction with methanol/ $\mathrm{HCl} 99 / 1(\mathrm{v} / \mathrm{v})$ as an extraction solvent using the Folin-Ciocalteu colorimetric method (Singleton \& Rossi, 1965). Gallic acid was employed as a calibration standard and results were expressed as gallic acid equivalents ( $\mathrm{mg}$ gallic acid/g of dried samples). The GP was used as a source of dietary fibre and polyphenols in the chicken diets.

Table 1 Proximate composition of grape pomace and total polyphenol content in grape pomace, control and $10 \%$ grape pomace diets ${ }^{1}$

\begin{tabular}{lccc}
\hline Parameters & Concentration & GP and diets & $\begin{array}{c}\text { Total polyphenols } \\
\text { (mg gallic acid equivalent /gDM) }\end{array}$ \\
\hline Dry matter $(\mathrm{g} / \mathrm{kg})$ & $914.5 \pm 0.37$ & GP & $33.92 \pm 0.48$ \\
Protein $(\mathrm{g} / \mathrm{kg})$ & $89.4 \pm 0.16$ & Control diet & $3.66 \pm 0.35$ \\
Fat $(\mathrm{g} / \mathrm{kg})$ & $70 \pm 0.91$ & $10 \%$ GP diet & $11.34 \pm 0.64$ \\
Ash $(\mathrm{g} / \mathrm{kg})$ & $32.6 \pm 0.43$ & & \\
Fibre $(\mathrm{g} / \mathrm{kg})$ & $302 \pm 1.97$ & \\
Ca $(\mathrm{g} / \mathrm{kg})$ & $5.2 \pm 0.09$ & \\
P $(\mathrm{g} / \mathrm{kg})$ & $2.9 \pm 0.08$ & \\
Gross energy $(\mathrm{kcal} / \mathrm{kg})$ & $4397.63 \pm 164.22$ & \\
\hline 'Data are the mean of three determinations $\pm \mathrm{SD}$ & \\
GP: grape pomace
\end{tabular}


A total of 200 day-old male broiler chicks (Ross 308 ) were purchased from a local hatchery. On arrival, all birds were weighed (average bodyweight $40 \pm 2 \mathrm{~g}$ ) and randomly assigned to one of four treatments, with five replicate pens/treatment and ten chickens/pen. Dietary treatments were formulated to meet or exceed the nutrient requirements of broilers provided by Ross Broiler Manual (Aviagen, 2014) (Table 2). Experimental diets consisted of i) control: corn, soybean diet (C); ii) C+10\% of GP; iii) $\mathrm{C}+10 \% \mathrm{GP}+\mathrm{T} 1$ (500 $\mathrm{mg} / \mathrm{kg}$ tannase enzyme); and iv) C+10\% GP+T2 (1000 mg/kg tannase enzyme). The straw was replaced with GP in the experimental diets. The feeding regimen consisted of starter (0 to 10 days), grower (11 to 24 days), and finisher diets (25 to 42 days). Chickens were raised in floor pens $(100 \times 120 \mathrm{~cm})$ and had free access to feed and water for the entire experimental period (days $0-42$ ). The room temperature gradually decreased from 33 to $22^{\circ} \mathrm{C}$ on day 28 and then remained constant. The lighting programme consisted of 20 hours of light and 4 hoursf darkness.

All experimental procedures were evaluated and approved by the Institutional Animal Care and Ethics Committee of Mohaghegh Ardabili University. An enzyme with tannase activity $(T)$ was used. It was supplied by Kikkoman Food Products Co (Edogawa Plant, Japan) and contained tannin acylhydrolase (500 U/g, EC 3.1.20).

Table 2 Ingredients and nutrient composition of basal diets

\begin{tabular}{lccc}
\hline Ingredients & Starter (days 0-10) & Grower (days 11-24) & Finisher (days 25-42) \\
\hline Corn & 42.53 & 44.52 & 48.75 \\
Soybean meal (44\% CP) & 41.18 & 37.87 & 32.76 \\
Soybean oil & 5.99 & 7.27 & 7.77 \\
Straw $^{4}$ & 5.93 & 6.40 & 7.06 \\
Grape pomace $^{3}$ & 0 & 0 & 0 \\
Dicalcium phosphate & 1.75 & 1.57 & 1.40 \\
Limestone $_{\text {Sodium chloride }}$ & 1.10 & 0.99 & 0.94 \\
Vitamin premix & 0.35 & 0.35 & 0.35 \\
Mineral premix & 0.25 & 0.25 & 0.25 \\
DL-Methionin & 0.25 & 0.25 & 0.25 \\
L-Lysine & 0.36 & 0.32 & 0.29 \\
L-Threonine & 0.22 & 0.15 & 0.14 \\
Calculated analysis & 0.10 & 0.07 & 0.05 \\
ME & & & \\
Crude protein & 2900 & 3000 & 3100 \\
Met + cystine & 22.22 & 20.81 & 18.89 \\
Lysine & 1.04 & 0.96 & 0.88 \\
Ether extract & 1.39 & 1.25 & 1.12 \\
Crude fibre & 7.87 & 9.19 & 9.80 \\
Ca & 6.20 & 6.20 & 6.20 \\
Available P & 0.93 & 0.84 & 0.77 \\
& 0.46 & 0.42 & 0.38
\end{tabular}

\footnotetext{
${ }^{1,2}$ Each $\mathrm{kg}$ of vitamin and trace mineral premix provided vitamin A: $900 \mathrm{IU}$; vitamin D: $2000 \mathrm{IU}$; vitamin E: $18 \mathrm{IU}$; vitamin $\mathrm{K}: 2 \mathrm{mg}$; vitamin B1: $1.8 \mathrm{mg}$; vitamin B2: $6.6 \mathrm{mg}$; vitamin B6: $3 \mathrm{mg}$; vitamin B12: $15 \mu \mathrm{g}$; niacin: $30 \mathrm{mg}$; pantothenic acid: $10 \mathrm{mg}$; biotin: $0.1 \mathrm{mg}$; folic acid, $1.25 \mathrm{mg}$; choline chloride: $200 \mathrm{mg}$; Fe: $50 \mathrm{mg}$; Cu: $10 \mathrm{mg}$; Mn: $100 \mathrm{mg}$; Zn: 85 mg; I: 0.8: $\mathrm{mg}$; Se: $0.2 \mathrm{mg}$

${ }^{3}$ Experimental diets consisted of i) control corn, soybean diet (C); ii) C+10\% GP; iii) C+10\% GP+T1 (500 mg/kg tannase enzyme); and iv) C + 10\% GP+T2 (1000 mg/kg tannase enzyme)

${ }^{4}$ The straw was replaced withgrape pomace in the experimental diets; $C P$ : crude protein; ME: metabolizable energy.
}

Birds and feed were weighed at 10,24 , and 42 days old. The values of average daily feed intake (ADFI) and ADG were recorded at various periods, and the feed-to-gain ratio was calculated. Mortality was 
recorded as it occurred. However, ADFI and F/G were corrected for the mortality of related groups. The economic evaluation was made in terms of feed cost per $\mathrm{kg}$ live weight gain during the differentiation and overall study period. At the end of the experiment (on day 42), after overnight fasting, two birds from each pen with bodyweight close to the pen mean were selected and slaughtered. Viscera were removed manually, and carcass characteristics (carcass yield, breast, thigh and abdominal fat) were determined. Then, internal organ weights were measured. All carcass data are presented based on percentage of live weight of each bird.

At 42 days old, two blood samples were collected from two birds/replicate following approximately eight hours fasting to determinate serum biochemical parameters and antioxidative status. The first samples were collected into vials containing EDTA and centrifuged for $10 \mathrm{~min}$ at $3000 \times \mathrm{g}$, then plasma was collected and stored at $-20^{\circ} \mathrm{C}$ until analysis. The concentrations of total protein, glucose, uric acid, triglycerides (TG), total cholesterol (CHOL), high-density lipoprotein cholesterol (HDL-C), low-density lipoprotein cholesterol (LDL-C), aspartate aminotransferase (AST) and alanine aminotransferase (ALT) in plasma samples were analysed withan automatic biochemical analyser (HITACHI912. Japan), following the instructions of the corresponding reagent kit (Audit Diagnostics Co. Ireland). The second blood sample was collected in a heparinized graduated centrifuge tube to obtain hemolysate. This was used to evaluate antioxidant status by measuring the malondialdehyde (MDA), superoxide dismutase (SOD) and glutathione peroxidase (GSH-Px) activity. GSH-Px activity was determined witha commercial enzyme kit (Ransel, RANDOX/RS-504 supplied by Randox Laboratories, Crumlin, UK). The SOD activity was determined with a commercial enzyme kit (Ransod, RANDOX/SD-125 supplied by Randox Laboratories). The MDA was analysed with a commercial kit (Biocore Diagnostik Co. Germany) and MDA was measured as a decomposed product of lipid peroxidation with 2-TBA using the colorimetric method with a spectrophotometer at a wavelength of $532 \mathrm{~nm}$ (Placer et al., 1966). At nine days old, Newcastle and influenza antigens were injected subcutaneously with $0.2 \mathrm{ml}$ per chick with a dual vaccine of Newcastle and influenza. Also, the chicks were orally vaccinated against Newcastle disease at 19 days old. To assay the primary and secondary antibody responses against sheep red blood cell (SRBC), at 14 and 35 days old, two birds/replicate were immunized intramuscularly with 0.25 $\mathrm{ml} \mathrm{10 \%} \mathrm{SRBC} \mathrm{in} \mathrm{phosphate-buffered} \mathrm{saline} \mathrm{(Leshchinsky} \mathrm{\&} \mathrm{Klasing,} \mathrm{2001).} \mathrm{On} \mathrm{days} 21$ and 42, the same birds were bled to determine antibody titers against SRBC and Newcastle disease virus. Subsequently, antibody titers against this virus were measured separately by haemagglutination inhibition $(\mathrm{HI})$. The $\mathrm{HI}$ antibodies were then converted to log2. The serum from each sample was collected, heat inactivated at $56^{\circ} \mathrm{C}$ for $30 \mathrm{~min}$, and then analysed for total $\operatorname{lgM}$ and $\lg$ (mercaptoethanol-resistant) anti-SRBC antibodies by the microhaemagglutination technique described by Qureshi \& Havanstein (1994).

Cellular immunity was assessed by a cutaneous basophil hypersensitivity test in vivo with phytohemagglutinin. At day 38, the toe web between the third and fourth digits of the right foot was measured in millimetres with a constant tension micrometer. Immediately after measurement,100 $\mu \mathrm{g}$ phytohemagglutinin, suspended in $0.10 \mathrm{ml}$ sterile saline, was injected into the toe web. The toe web swelling was measured 24 and 48 hours after injection. The response was determined by subtracting the skin thickness of the first measurement from that of the second measurement (Corrier \& DeLoach, 1990). Lymphoid organs, including the spleen and bursa of Fabricius, were evaluated after slaughter on day 42 of the experiment.

At 40 days old, clean stainless steel collection trays were placed under each cage, and the excreta of the birds was collected for 48 hours. A subsample of excreta was collected in polyethylene bags and stored at $-20^{\circ} \mathrm{C}$ to determine polyphenol content.

At 42 days old, fifteen birds per treatment were euthanized with carbon dioxide (100\%). The ileum was quickly dissected and the content expressed by gentle manipulation into a plastic container and stored a -20 ${ }^{\circ} \mathrm{C}$. Digesta were pooled from three birds of each replicate inthe same treatment. Ileal contents were ground ( $1 \mathrm{~mm}$ screen) and used to determine the polyphenol content. On day 42, two chicks from each replicate were killed afterovernight fasting to limit intestinal throughput. The whole length of the small intestine was removed, and samples were taken from the duodenum, jejunum, and ileum. The samples were flushed gently twice with physiological saline $(1 \% \mathrm{NaCl})$ to remove intestinal contents and placed in $10 \%$ formalin for fixation. The 5-6 $\mu$ sections were made by the paraffin embedding method and stained with haematoxylineosin. Micrometrical analysis was carried out with a Dino-Lite digital microscope, digital Dino-Lite eye-piece and Dino-Capture 2 software on microphotographs. The variables that were measured were villus height, crypt depth and thickness of the muscularis layer. The ratio of villus height to crypt depth was calculated (Hashemi et al., 2012).

Ten birds/replicate on day 42 were selected and killed by cervical dislocation. The carcasses were subsequently opened and the entire gastrointestinal tract was removed aseptically. Samples (1g) from the contents of the ceca were collected immediately and added to $5 \mathrm{ml}$ glycerine in glass containers. Digesta samples were diluted in a $0.85 \%$ sterile saline solution to enumerate lactobacilli and escherichia coli by 
conventional microbiological techniques using selective agar media as described by Jin et al.(1998). All microbiological analyses were conducted in duplicate, and the average values were used in the statistical analysis. Lactobacillus bacteria were grown on Rogosa SL agar (Merck, Darmstadt, Germany), and Escherichia coli was grown on McConkey agar (Merck, Darmstadt, Germany). Selective agar used to enumerate Lactobacillus spp. was incubated anaerobically for 48 hours at $37^{\circ} \mathrm{C}$, and selective agar used to enumerate Escherichia coli was incubated aerobically for 24 hours at $37{ }^{\circ} \mathrm{C}$. Bacterial numbers were expressed as $\log 10 \mathrm{cfu} / \mathrm{g}$ of caecal digesta.

On day 42, two chicks from each replicate were killed and samples were taken from the liver of each bird. Liver weights were measured and all data are presented based on percentage of live weight of each bird. Then the liver tissue samples were collected and samples were fixed in $10 \%$ formalin and transmitted to the histological laboratory to detect histopathological changes. The $5 \mu$ sections were made by the paraffin embedding method and stained with haematoxylin-eosin. The micrometrical analysis (diameters of cells and nucleus) was done with the Dino-Lite digital microscope, digital Dino-Lite eyepiece and Dino-Capture 2 software on microphotographs.

Data were analysed in a completely randomized design using the general linear model (GLM) procedures of SAS (SAS Institute Inc, 2001). When the differences were significant $(P<0.05)$, mean values between treatments were compared using the Duncan test.

\section{Results}

The effects of various dietary treatments on broiler BW, ADG, ADFI, and F/G are shown in Table 3. At 10 days old, the BW of birds fed the diet supplemented with GP was lower $(P<0.05)$ compared with the control group. Furthermore, broilers fed the diet supplemented with GP had lower $(P<0.05)$ ADG in the

Table 3 Response of broiler chickens, in terms of bodyweight, average daily gain, average daily feed intake and feed-to-gain ratio

\begin{tabular}{|c|c|c|c|c|c|c|}
\hline \multirow{2}{*}{ Item } & \multicolumn{4}{|c|}{ Dietary treatments ${ }^{1}$} & \multirow[b]{2}{*}{ SEM } & \multirow[b]{2}{*}{ P-value } \\
\hline & Control & C+10 GP & $\mathrm{C}+10 \mathrm{GP}+\mathrm{T} 1$ & $\mathrm{C}+10 \mathrm{GP}+\mathrm{T} 2$ & & \\
\hline \multicolumn{7}{|l|}{ BW, g } \\
\hline $10 d$ & $248.32^{\mathrm{a}}$ & $214.32^{b}$ & $202.64^{\mathrm{b}}$ & $217.04^{b}$ & 5.836 & 0.022 \\
\hline $24 d$ & 979.68 & 902.61 & 910.87 & 912.96 & 15.754 & 0.291 \\
\hline $42 d$ & 2416.20 & 2272.46 & 2275.92 & 2358.74 & 40.280 & 0.560 \\
\hline \multicolumn{7}{|l|}{$A D G, g$} \\
\hline Starter $(0-10 d)$ & $20.52^{\mathrm{a}}$ & $17.15^{\mathrm{b}}$ & $15.96^{b}$ & $17.17^{b}$ & 0.580 & 0.019 \\
\hline Grower (11-24 d) & 52.24 & 49.16 & 50.58 & 49.70 & 1.089 & 0.796 \\
\hline Finisher (25-42 d) & 79.80 & 76.09 & 75.83 & 80.31 & 2.273 & 0.867 \\
\hline Overall (0-42 d) & 56.50 & 53.08 & 53.16 & 55.13 & 0.959 & 0.560 \\
\hline \multicolumn{7}{|l|}{ ADFI, g } \\
\hline Starter $(0-10 d)$ & 32.80 & 24.60 & 23.37 & 21.88 & 1.587 & 0.052 \\
\hline Grower (11-24 d) & 101.68 & 93.96 & 98.17 & 97.34 & 1.544 & 0.392 \\
\hline Finisher (25-42 d) & 161.95 & 150.30 & 151.45 & 165.28 & 5.435 & 0.732 \\
\hline Overall (0-42 d) & 113.46 & 101.90 & 104.26 & 109.24 & 2.087 & 0.207 \\
\hline \multicolumn{7}{|l|}{ Feed/gain g } \\
\hline Starter $(0-10 d)$ & 1.60 & 1.42 & 1.46 & 1.26 & 0.058 & 0.235 \\
\hline Grower (11-24 d) & 1.96 & 1.91 & 1.94 & 1.96 & 0.026 & 0.933 \\
\hline Finisher (25-42 d) & 2.03 & 1.98 & 1.98 & 2.05 & 0.038 & 0.909 \\
\hline Overall (0-42 d) & 2.00 & 1.92 & 1.96 & 1.98 & 0.015 & 0.241 \\
\hline
\end{tabular}


starter (days 0-10) period compared with the control group. In contrast, the addition of GP and tannase had no significant effect on BW, ADG, ADFI, and F/G during the grower (days 11-24) and finisher (days 25-42) experimental periods.

The main effects of the diets on carcass characteristics, abdominal fat, and yields of broilers at 42 days old are presented in Table 4. There were no significant $(P>0.05)$ effects of the diets on carcasses, abdominal fat, livers or relative heart weights of broilers.

Table 4 The relative weights of meat parts, liver, heart and abdominal fat of broiler fed different diets at 42 days of age

\begin{tabular}{lcccccc}
\hline \multirow{2}{*}{ Dietary treatments } & Carcass & Breast & Thigh & Liver & Heart & Abdominal fat \\
\cline { 2 - 6 } & \multicolumn{5}{c}{ (\% of live weight) } \\
\hline Control & 67.00 & 27.17 & 18.79 & 2.26 & 0.431 & 1.60 \\
C+10 GP & 65.89 & 29.31 & 17.84 & 2.15 & 0.432 & 1.59 \\
C+10 GP+T1 & 65.75 & 26.50 & 18.11 & 2.16 & 0.374 & 1.40 \\
C+10 GP+T2 & 64.06 & 25.79 & 18.50 & 2.26 & 0.432 & 1.62 \\
SEM & 0.598 & 0.588 & 0.178 & 0.052 & 0.015 & 0.093 \\
P-value & 0.405 & 0.169 & 0.258 & 0.801 & 0.478 & 0.853
\end{tabular}

${ }^{1}$ Diets supplemented (+) with 10\% grape pomace (10GP) and tannase enzyme (500 mg/kg of tannase (T1), and 1000 $\mathrm{mg} / \mathrm{kg}$ of tannase (T2))

The effects of the dietary treatments on plasma biochemical parameters are reported in Table 5 . Feeding GP and tannase diets decreased serum TG $(P<0.01)$. Broilers fed the diet containing $10 \% \mathrm{GP}+500$ $\mathrm{mg} / \mathrm{kg}$ tannase had the lowest TG concentrations $(60.71 \mathrm{mg} / \mathrm{dl})$ of the experimental groups (Table 5$)$. In comparison with the control group,a significant reduction $(P<0.05)$ in LDL-C levels was observed for GP-fed groups. Broilers fed the diet containing 10\% GP had lower LDL-C concentration $(11.85 \mathrm{mg} / \mathrm{dl})$. HDL-C level was increased $(P<0.05)$ by dietary GP supplementation and broilers fed the diet containing $10 \%$ GP had the highest HDL-C concentration (102.93 $\mathrm{mg} / \mathrm{dl})$. There were no significant differences in serum parameters, including total protein, uric acid, glucose and cholesterol concentrations, in any of the treatments (Table 5).

Table 5 Effects of grape pomace and tannase supplementation in chicken diets on serum biochemical parameters

\begin{tabular}{|c|c|c|c|c|c|c|c|}
\hline Dietary treatments ${ }^{1}$ & $\begin{array}{l}\text { Total protein } \\
\text { (g/dl) }\end{array}$ & $\begin{array}{l}\text { Glucose } \\
\text { (mg/dl) }\end{array}$ & $\begin{array}{c}\text { Total } \\
\text { cholesterol } \\
(\mathrm{mg} / \mathrm{dl})\end{array}$ & $\underset{(\mathrm{mg} / \mathrm{dl})}{\mathrm{TG}}$ & $\begin{array}{l}\text { HDL-C } \\
\text { (mg/dl) }\end{array}$ & $\begin{array}{l}\text { LDL-C } \\
(\mathrm{mg} / \mathrm{dl})\end{array}$ & $\begin{array}{c}\text { Uric acid } \\
\text { (mg/dl) }\end{array}$ \\
\hline Control & 5.13 & 226.86 & 128.57 & $97.29^{\mathrm{a}}$ & $68.20^{\mathrm{b}}$ & $18.71^{\mathrm{a}}$ & 5.28 \\
\hline $\mathrm{C}+10 \mathrm{GP}$ & 5.52 & 219.29 & 107.00 & $63.57^{\mathrm{b}}$ & $102.93^{\mathrm{a}}$ & $11.85^{\mathrm{b}}$ & 5.20 \\
\hline $\mathrm{C}+10 \mathrm{GP}+\mathrm{T} 1$ & 5.10 & 214.14 & 109.85 & $60.71^{b}$ & $88.55^{\mathrm{ab}}$ & $14.21^{\mathrm{b}}$ & 4.21 \\
\hline $\mathrm{C}+10 \mathrm{GP}+\mathrm{T} 2$ & 5.47 & 221.00 & 117.00 & $61.71^{b}$ & $80.93^{\mathrm{ab}}$ & $14.71^{\mathrm{ab}}$ & 4.64 \\
\hline SEM & 0.144 & 3.910 & 2.20 & 4.205 & 4.413 & 0.805 & 0.398 \\
\hline P-value & 0.659 & 0.740 & 0.113 & 0.009 & 0.032 & 0.015 & 0.775 \\
\hline
\end{tabular}

\footnotetext{
${ }^{\mathrm{a}, \mathrm{b}}$ Means in the same column without a common superscript differ significantly $(P<0.05)$

${ }^{1}$ Diets supplemented (+) with $10 \%$ grape pomace (10GP) and tannase enzyme (500 mg/kg of tannase (T1) and 1000 $\mathrm{mg} / \mathrm{kg}$ of tannase (T2)

TG: triglyceride;HDL-C: high-density lipoprotein cholesterol; LDL-C: low-density lipoprotein cholesterol
}

The effects of dietary treatments on SOD, GSH-Px activities and MDA concentration in serum of broilers at 42 days old are shown in Table 6 . In contrast with the control group, supplementation with GP elevated $(P<0.05)$ SOD and GSH-Px $(P<0.01)$ activities and depressed $(P<0.01)$ MDA in serum (Table 6). 
Table 6 Concentration of plasma superoxide dismutase, glutathione peroxidase and malondialdehyde in chickens fed diets supplemented with grape pomace and tannase

\begin{tabular}{|c|c|c|c|c|c|c|}
\hline \multirow{2}{*}{ Items } & \multicolumn{4}{|c|}{ Dietary treatments ${ }^{1}$} & \multirow[b]{2}{*}{ SEM } & \multirow[b]{2}{*}{ P-value } \\
\hline & Control & $\mathrm{C}+10 \mathrm{GP}$ & $\mathrm{C}+10 \mathrm{GP}+\mathrm{T} 1$ & $\mathrm{C}+10 \mathrm{GP}+\mathrm{T} 2$ & & \\
\hline $\mathrm{SOD}(\mathrm{U} / \mathrm{ml})$ & $103.63^{b}$ & $142.70^{\mathrm{a}}$ & $133.23^{a b}$ & $164.01^{\mathrm{a}}$ & 7.072 & 0.014 \\
\hline GSH-Px(U/ml) & $112.57^{\mathrm{C}}$ & $133.86^{\mathrm{bc}}$ & $147.71^{b}$ & $182.31^{a}$ & 7.082 & 0.001 \\
\hline $\mathrm{MDA}(\mathrm{nmol} / \mathrm{ml})$ & $7.84^{\mathrm{a}}$ & $5.34^{\mathrm{b}}$ & $4.20^{\mathrm{C}}$ & $4.13^{c}$ & 0.319 & 0.001 \\
\hline
\end{tabular}

The effects of dietary treatment on antibody production, hypersensitivity and lymphoid organ weights in broilers are shown in Tables 7 and 8. Antibody titers against Newcastle disease virus at 42 days old were higher $(P<0.05)$ in broilers fed the diet containing 10\% GP than in those fed the control diet. The addition of GP to the diets had a significant impact on the anti-SRBC titers of total and IgM antibodies at 21 days old. In contrast, IgG antibodies were not affected by dietary treatments (Table 7).

Table 7 Effects of grape pomace and tannase supplementation in chicken diets on antibody production $(\log 2)$

\begin{tabular}{|c|c|c|c|c|c|c|}
\hline \multirow{2}{*}{ Items } & \multicolumn{4}{|c|}{ Dietary treatments ${ }^{1}$} & \multirow{2}{*}{ SEM } & \multirow{2}{*}{ P-value } \\
\hline & Control & $\mathrm{C}+10 \mathrm{GP}$ & $\mathrm{C}+10 \mathrm{GP}+\mathrm{T} 1$ & $\mathrm{C}+10 \mathrm{GP}+\mathrm{T} 2$ & & \\
\hline \multicolumn{7}{|c|}{ NDV antibody titer } \\
\hline $21 d$ & 4 & 4.2 & 3.9 & 3.7 & 0.147 & 0.699 \\
\hline $42 d$ & $4.4^{\mathrm{b}}$ & $6.2^{\mathrm{a}}$ & $5.5^{\mathrm{ab}}$ & $5^{a b}$ & 0.237 & 0.044 \\
\hline \multicolumn{7}{|c|}{ SRBC antibody titer } \\
\hline Primary titer & $2.40^{\mathrm{b}}$ & $3.40^{\mathrm{a}}$ & $2.60^{\mathrm{b}}$ & $2.60^{b}$ & 0.142 & 0.048 \\
\hline $\lg G$ & 1.40 & 1.60 & 1.60 & 1.40 & 0.114 & 0.879 \\
\hline $\lg M$ & $1.00^{b}$ & $1.80^{\mathrm{a}}$ & $1.00^{\mathrm{b}}$ & $1.20^{b}$ & 0.099 & 0.002 \\
\hline Secondary titer & $2.40^{\mathrm{b}}$ & $4.30^{\mathrm{a}}$ & $3.20^{\mathrm{b}}$ & $3.00^{b}$ & 0.213 & 0.010 \\
\hline $\lg G$ & $0.60^{b}$ & $2.70^{a}$ & $1.50^{b}$ & $1.40^{b}$ & 0.208 & 0.002 \\
\hline $\lg M$ & 1.80 & 1.60 & 1.70 & 1.60 & 0.083 & 0.814 \\
\hline
\end{tabular}

\footnotetext{
$\overline{a, b}$ Means in the same row without a common superscript differ significantly $(P<0.05)$

${ }^{1}$ Diets supplemented (+) with $10 \%$ grape pomace ( OGP) and tannase enzyme $(500 \mathrm{mg} / \mathrm{kg}$ of tannase (T1) and 1000 $\mathrm{mg} / \mathrm{kg}$ of tannase (T2); NDV: Newcastle disease virus; SRBC: sheep red blood cell
}

In the secondary response, there was an increase $(P<0.05)$ in total anti-SRBC titers and $\lg \mathrm{G}$ antibodies in broilers fed the diet containing 10\% GP compared with the other experimental groups. In contrast, during the secondary challenge, the SRBC-specific IgM titer in the broiler serum showed no differences across treatments. Phytohaemagglutinin injection increased $(P<0.05)$ toe web thickness within 24 and 48 hours of injection in birds fed the diet containing $10 \%$ GP $+500 \mathrm{mg} / \mathrm{kg}$ tannase compared with the control group (Table 8). In the present study, the relative immune organ weights were not affected by dietary treatments. 
Table 8 Effects of grape pomace and tannase supplementation in chicken diets on hypersensitivity and lymphoid organ weights

\begin{tabular}{|c|c|c|c|c|c|c|}
\hline \multirow{2}{*}{ Items } & \multicolumn{4}{|c|}{ Dietary treatments ${ }^{1}$} & \multirow[b]{2}{*}{ SEM } & \multirow[b]{2}{*}{ P-value } \\
\hline & Control & $\mathrm{C}+10 \mathrm{GP}$ & $\mathrm{C}+10 \mathrm{GP}+\mathrm{T1}$ & $\mathrm{C}+10 \mathrm{GP}+\mathrm{T} 2$ & & \\
\hline \multicolumn{7}{|c|}{ Hypersensitivity $(\mathrm{mm}), \mathrm{d} 38$} \\
\hline 24 hours after & $0.87^{\mathrm{b}}$ & $0.81^{b}$ & $1.23^{\mathrm{a}}$ & $0.77^{\mathrm{b}}$ & 0.066 & 0.045 \\
\hline 48 hours after & $0.63^{\mathrm{b}}$ & $0.64^{b}$ & $0.94^{\mathrm{a}}$ & $0.60^{\mathrm{b}}$ & 0.048 & 0.045 \\
\hline \multicolumn{7}{|c|}{ Lymphoid organ weight (g/kg BW) } \\
\hline Spleen & 0.106 & 0.107 & 0.092 & 0.103 & 0.005 & 0.731 \\
\hline Bursa of Fabricius & 0.048 & 0.045 & 0.062 & 0.050 & 0.003 & 0.463 \\
\hline
\end{tabular}

\footnotetext{
${ }^{a, b}$ Means in the same row without a common superscript differ significantly $(P<0.05)$

${ }^{1}$ Diets supplemented $(+)$ with $10 \%$ of grape pomace (10GP) and tannase enzyme (500 mg/kg of tannase (T1) and 1000 $\mathrm{mg} / \mathrm{kg}$ of tannase (T2))
}

The total ileal and excreta polyphenol contents of birds fed diets containing GP and tannase are reported in Table 9. Birds fed GP diets showed higher ileal and excreta polyphenol contents than those fed control diets. The inclusion of tannase in GP diets increased ileal and excreta polyphenol content, being higher in animals fed diets containing $10 \% \mathrm{GP}+500 \mathrm{mg} / \mathrm{kg}$ tannase.

Table 9 Effect of diets containing grape pomace and tannase on ileal and excreta total polyphenol content expressed as $\mathrm{mg}$ gallic acid equivalent per gram of dry matter

\begin{tabular}{lcc}
\hline Dietary treatments $^{1}$ & \multicolumn{2}{c}{ Total polyphenol (mg GAE/g DM) } \\
\hline & Ileal & Excreta \\
Control & $2.139^{\mathrm{b}}$ & $5.179^{\mathrm{c}}$ \\
C+10 GP & $5.867^{\mathrm{a}}$ & $6.379^{\mathrm{b}}$ \\
C+10 GP+T1 & $6.044^{\mathrm{a}}$ & $7.991^{\mathrm{a}}$ \\
C+10 GP+T2 & $5.954^{\mathrm{a}}$ & $7.429^{\mathrm{a}}$ \\
SEM & 0.468 & 0.276 \\
P-value & 0.011 & 0.001
\end{tabular}

${ }^{a, b, c}$ Means in the same column without a common superscript differ significantly $(P<0.05)$

${ }^{1}$ Diets supplemented (+) with $10 \%$ of grape pomace (10GP) and tannase enzyme (500 mg/kg of tannase (T1) and 1000 $\mathrm{mg} / \mathrm{kg}$ of tannase (T2))

GAE: gallic acid equivalent

The histomorphometrical measurement results of the various parts of small intestine of broiler chicks are shown in Table 10. The muscularis thickness of the chicken duodenum was decreased in the Trial 3 compared with the control groups $(P<0.05)$, but villus height and crypt depth were not affected. In the jejunum parts of small intestine, villus height and villus height/crypt depth ratio were reduced $(P<0.01)$ in birds fed the GP diet compared with control groups (Table 10). There were no significant effects of diets on villus height and the villus height/crypt depth ratio inthe ileum $(P>0.05)$. Muscularis thickness and crypt depth were decreased in birds fed GP supplemented with tannase compared with those fed the control. 
Table 10 Effects of grape pomace and tannase supplementation in chicken diets on morphology of the small intestine at 42 days of age

\begin{tabular}{|c|c|c|c|c|c|c|}
\hline \multirow[t]{2}{*}{ Items } & \multicolumn{4}{|c|}{ Dietary treatments ${ }^{1}$} & \multirow{2}{*}{ SEM } & \multirow{2}{*}{ P-value } \\
\hline & Control & C+10 GP & $\mathrm{C}+10 \mathrm{GP}+\mathrm{T} 1$ & $\mathrm{C}+10 \mathrm{GP}+\mathrm{T} 2$ & & \\
\hline \multicolumn{7}{|l|}{ Duodenum } \\
\hline Villus height $(\mu \mathrm{m})$ & 1295.9 & 927.8 & 1071.3 & 1263.3 & 68.290 & 0.176 \\
\hline Crypt depth $(\mu \mathrm{m})$ & 296.37 & 299.20 & 249.45 & 310.06 & 11.198 & 0.239 \\
\hline Villus height/crypt depth & 4.36 & 3.15 & 4.33 & 4.09 & 0.223 & 0.183 \\
\hline Muscularis thickness $(\mu \mathrm{m})$ & $149.86^{\mathrm{a}}$ & $110.25^{\mathrm{ab}}$ & $84.28^{\mathrm{b}}$ & $98.11^{\mathrm{b}}$ & 9.274 & 0.038 \\
\hline \multicolumn{7}{|l|}{ Jejunum } \\
\hline Villus height $(\mu \mathrm{m})$ & $1198.5^{\mathrm{a}}$ & $700.6^{b}$ & $682.41^{b}$ & $647.43^{b}$ & 74.357 & 0.001 \\
\hline Crypt depth $(\mu \mathrm{m})$ & 300.29 & 262.88 & 283.94 & 266.27 & 15.079 & 0.850 \\
\hline Villus height/crypt depth & $3.98^{\mathrm{a}}$ & $2.68^{\mathrm{b}}$ & $2.46^{\mathrm{b}}$ & $2.43^{\mathrm{b}}$ & 0.201 & 0.001 \\
\hline Muscularis thickness $(\mu \mathrm{m})$ & 143.81 & 132.63 & 94.68 & 134.27 & 10.496 & 0.406 \\
\hline \multicolumn{7}{|l|}{ Ileum } \\
\hline Villus height $(\mu \mathrm{m})$ & 665.19 & 627.07 & 517.81 & 709.41 & 32.018 & 0.171 \\
\hline Crypt depth $(\mu \mathrm{m})$ & $285.12^{a}$ & $211.31^{b}$ & $193.81^{b}$ & $248.63^{a b}$ & 13.453 & 0.041 \\
\hline Villus height/crypt depth & 2.40 & 2.98 & 2.68 & 2.84 & 0.136 & 0.540 \\
\hline Muscularis thickness $(\mu \mathrm{m})$ & $147.14^{\mathrm{a}}$ & $95.83^{b}$ & $96.65^{b}$ & $94.14^{\mathrm{b}}$ & 7.103 & 0.002 \\
\hline
\end{tabular}

Bacteriological analysis results at 42 days old are detailed in Table 11. In the caecal digesta, the inclusion of GP in the chicken diets reduced $(P<0.05)$ the concentration of Escherichia coli and increased $(P$ $<0.05$ ) that of Lactobacillus compared with the control diet (Table 11). The caecal populations of Lactobacillus were higher in broilers fed the $10 \%$ GP or $10 \%$ GP $+500 \mathrm{mg} / \mathrm{kg}$ tannase diet compared with birds fed the control diet at 42 days old. In contrast,Trial 4 broilers exhibited lower caecal Escherichia coli counts than other experimental groups.

Table 11 Effects of grape pomace and tannase supplementation in chicken diets on caecal bacterial content at 42 days of age

\begin{tabular}{|c|c|c|c|c|c|c|}
\hline \multirow{2}{*}{$\begin{array}{l}\text { Microbial activity } \\
(\mathrm{cfu})^{2}\end{array}$} & \multicolumn{4}{|c|}{ Dietary treatments ${ }^{1}$} & \multirow{2}{*}{ SEM } & \multirow{2}{*}{ P-value } \\
\hline & Control & $C+10 \mathrm{GP}$ & $\mathrm{C}+10 \mathrm{GP}+\mathrm{T} 1$ & $\mathrm{C}+10 \mathrm{GP}+\mathrm{T} 2$ & & \\
\hline Lactobacillus & $6.53^{\mathrm{b}}$ & $7.12^{\mathrm{a}}$ & $7.03^{\mathrm{ab}}$ & $6.54^{\mathrm{b}}$ & 0.100 & 0.041 \\
\hline Escherichia coli & $6.57^{\mathrm{a}}$ & $6.51^{\mathrm{a}}$ & $6.73^{\mathrm{a}}$ & $5.96^{\mathrm{b}}$ & 0.106 & 0.045 \\
\hline
\end{tabular}

The effects of dietary treatment on liver histology and concentrations of liver function indicators AST and ALT are summarized in Table 12. A significant statistical elevation $(P<0.05)$ in the activity of AST and ALT enzymes was observed in GP-fed groups compared with the control. 
Table 12 Effects of grape pomace and tannase supplementation in chicken diets on liver histomorphometric parameters, aspartate aminotransferase and alanine aminotransferase in plasma

\begin{tabular}{|c|c|c|c|c|c|c|}
\hline \multirow{2}{*}{ Item } & \multicolumn{4}{|c|}{ Dietary treatments ${ }^{1}$} & \multirow{2}{*}{ SEM } & \multirow{2}{*}{ P-value } \\
\hline & Control & $\mathrm{C}+10 \mathrm{GP}$ & $\mathrm{C}+10 \mathrm{GP}+\mathrm{T} 1$ & $\mathrm{C}+10 \mathrm{GP}+\mathrm{T} 2$ & & \\
\hline $\begin{array}{l}\text { Diameters of } \\
\text { cells }(\mu \mathrm{m})\end{array}$ & 8.24 & 7.98 & 8.31 & 8.31 & 0.119 & 0.784 \\
\hline Diameters ofnucleus $(\mu \mathrm{m})$ & 4.43 & 4.81 & 4.63 & 4.65 & 0.088 & 0.563 \\
\hline $\operatorname{ALT}(\mathrm{u} / \mathrm{l})$ & $12.42^{\mathrm{b}}$ & $11.57^{\mathrm{b}}$ & $13.28^{\mathrm{ab}}$ & $15.85^{\mathrm{a}}$ & 0.586 & 0.047 \\
\hline $\mathrm{AST}(\mathrm{u} / \mathrm{l})$ & $193.57^{b}$ & $333.00^{\mathrm{a}}$ & $352.00^{\mathrm{a}}$ & $316.43^{\mathrm{a}}$ & 19.196 & 0.007 \\
\hline
\end{tabular}

${ }^{a, b}$ Means in the same row without a common superscript differ significantly $(P<0.05)$.

${ }^{1}$ Diets supplemented (+) with $10 \%$ of grape pomace (10GP) and tannase enzyme (500 mg/kg of tannase (T1) and 1000 $\mathrm{mg} / \mathrm{kg}$ of tannase (T2)

ALT:alanine aminotransferase; AST: aspartate aminotransferase.

No significant $(P>0.05)$ histopathological changes were seen for birds fed GP and different levels of tannase compared with the control group. There were no significant $(P>0.05)$ effects of feeding diets on liver weights in broilers (Table 4).

\section{Discussion}

There are few references in the literature to the use of grape by-products in chicken feed. Hughes et al. (2005) and Lau \& King (2003) reported growth depression in chickens fed diets containing grape seed extract (GSE). In contrast, Hajati et al. (2015) reported that GSE supplementation at the levels of $300 \mathrm{mg} / \mathrm{kg}$ diet improved the bodyweight of broilers. Recent works by Brenes et al. (2008) and Chamorro et al. (2013) showed that concentrations of up to $6 \%$ GP and $0.25 \%$ GSE could be used in chicken feed without modification in performance, in the size of the digestive organs or the ileal digestibility of protein and in amino acids. Gape pomace contains high levels of fibre and polymeric polyphenols as procyanidins with the capacity to bind and precipitate dietary and endogenous proteins. Therefore, the incorporation of GP at high doses in chicken diets might impair nutrient digestion and growth. The utilization of enzymes with the capacity to hydrolyse complex polyphenols in GP might allow the use of higher doses of GP in chicken diets. Thus, in the present study, high doses of GP were used. Because all diets were formulated to contain the same fibre content, differences should be attributed to the polyphenol content.

The results of the current study showed that dietary inclusion of up to 10 percent GP did not affect chick growth performance. Consequently, the use of the tannase enzyme did not enhance the parameters. In agreement with the current results, Chamorro et al. (2015) reported that the inclusion of enzymes (carbohydrases and tannase, $500 \mathrm{mg} / \mathrm{kg}$ ) in chicken diets containing GP (5\% and 10\%) modified the polyphenol polymeric structures in the ileal content, with increased concentrations of gallic acid, catechin and epicatechin in birds fed carbohydrases, and of gallic acid, catechin, epicatechin, procyanidins PB1 and PB2 and epicatechin gallate. These findings show that the inclusion of enzymes in diets containing GP increased the amount of total polyphenol released in the intestine, although this effect was not accompanied by an increase in performance. There were no significant effects of the diets on carcasses, abdominal fat and relative liver or heart weights in broilers. These results are in agreement with those of Brenes et al. (2008), who reported that the inclusion of graded concentrations of GP did not affect relative abdominal fat, liver, pancreas, and spleen weight.

In this study, serum total protein and cholesterol levels were unchanged. This agrees with studies that reported that including plant extracts rich in polyphenols such as rosemary, grape, citrus and marigold at 5 $\mathrm{g} / \mathrm{kg}$ diet in rats (Gladine et al., 2007) and inclusion of GP in laying hen diets up to 6 percent by Kara et al. (2015) has no effect on serum protein and cholesterol. Hajati et al. (2015) reported that GSE supplementation $(150,300,450 \mathrm{mg} / \mathrm{kg})$ decreased the concentration of serum glucose. In contrast, in the current study, GP supplementation of chicken diets did not have asignificant impact on serum glucose. In agreement with the current results, Ozgan (2008) stated that the plasma glucose level was not affected by the inclusion of $1.0 \%$ grape seed oil in laying hen diets. Similar to the results of this study, administration of GSE reduced blood levels of total TG, LDL-C and increased HDL-C in broilers (Hajati et al., 2015). The concentration of uric acid in broiler serum was not affected by dietary treatments $(P>0.05)$. Antioxidant activity is the most notable bioactivity of phenolic compounds from GP (Xia et al., 2010; Georgiev et al., 
2014). In vitro and in vivo studies have shown that flavonoids in wine by-products behave like free radical scavengers by acting as powerful antioxidants and metal chelators. This inhibits formation of the superoxide ion and indirectly inhibits redox-sensitive transcription factors and pro oxidant enzymes (Puiggros et al., 2005). Polyphenols also activate antioxidant enzymes, reduce a tocopherol radical (tocopheroxyls), inhibit oxidases, and increase levels of uric acid and substances of low molecular weight. The antioxidative properties of polyphenols result mainly from their ability to donate hydrogen from hydroxyl groups positioned along the aromatic ring in order to terminate the free radical oxidation of lipids and other biomolecules (Foti et al., 1994).

The current findings are consistent with those of Seven et al. (2008), who reported that feeding plant extracts rich in phenolic compounds resulted in an increase in blood GSH-Px activity of chronic heatexposed broiler chickens. Similar positive changes in plasma MDA and SOD levels to those in the current study were reported in a study of layer chickens fed with citrus flavonoids (Lien et al., 2008). Results from this study confirm that dietary GP can delay lipid oxidation in plasma and reduce the potential risk induced by lipid oxidation. In the present study, the addition of tannase to diets containing GP reversed the beneficial effect observed in GP diets. Birds fed with GP diet supplemented with $1000 \mathrm{mg} / \mathrm{kg}$ tannase showed higher SOD and GSH-Px activities and lower MDA concentration in comparison with other experimental groups (Table 6).

The addition of GP and tannase in the chicken diets could increase the cellular and humoral immune responses. In poultry production, it is important to improve immunity to prevent infectious diseases. A variety of factors such as vaccination failure, infection by immune-suppressive diseases, and abuse of antibiotics can induce immunodeficiency. Grape pomace is particularly rich in a wide range of polyphenols. Konowalchuk \& Speirs (2009) reported that grape seed proanthocyanidins show up to 50 times more antioxidant activity than vitamin E. Immunity is influenced by oxidative stress and improving the antioxidant status of the animal may enhance its immunity. Similar to the current data, lqbal et al. (2015) found that broilers fed the grape polyphenols diets showed higher $(P<0.05)$ antibody titers against ND virus than those fed the control diet. Additionally, Acamovic \& Brooker (2005) reported immunostimulating activity of polyphenols and oregano essential oil with respect to the mononuclear phagocyte system, cell, and humoral immunity. Today, there is compelling evidence that suggests that the mechanisms by which plant polyphenols exert their properties, such a mode of action would induce the inhibition of key enzymes, modulate cell receptors or transcription factors, and perturb protein (or peptide) aggregates, which can regulate cell functions related for example to growth and proliferation, inflammation, apoptosis, angiogenesis, metastasis, and immune responses by affecting signal transduction pathways (Zhu et al., 1997; Yang et al., 2009).

Immune organs, including the spleen and bursa of Fabricius, are considered important sites for antigen recognition and activation of immune cells (Akter et al., 2006). The relative weight of the spleen and bursa reflect the host's ability to produce $T$ and $B$ lymphocytes during an immune response. In the present study, the relative immune organ weights were not significantly affected by dietary treatments. In agreement, Brenes et al. (2008) and Rahimi et al. (2011) showed no significant differences in the relative weight of the spleen and bursa in broilers fed a diet containing GP concentrate and thyme compared with the control groups. The biological effect of polyphenols depends on their availability. Monomeric and some oligomeric polyphenols have been found to be absorbed in the small intestine, while polymeric forms are poorly absorbed, and must be hydrolysed by the intestinal microbiota (Gonthier et al., 2003). As expected, birds fed GP diets showed higher intestinal (ileal and excreta) total polyphenol contents than those fed control diets. Recent studies have estimated that the amount of non-absorbable polyphenols reaching the colon is high and microbe-derived phenolic metabolites excreted in urine represent the largest proportion of polyphenol intake (Monagas et al., 2010).

Birds lack a specific urinary excretory system. Consequently the excreta of chicks are composed of urine and undigested compounds. Thus, the total polyphenols that were determined in excreta in this experiment included phenolic substances from undigested and microbe-derived phenolic metabolites. This might explain why the amount of phenolic compounds in excreta was higher than those obtained from the ileal content. The authors hypothesized that the use of enzyme with tannase activities might hydrolyse the complex polyphenol structure of grape pomace into more simple phenols, enhancing the amount of bioactive available substances and, therefore, its antioxidant capacity. Lafay \& Gil-Izquierdo (2008) reported that low molecular weight phenolic compounds can be much more easily absorbed and might contribute more directly to beneficial health effects.

Mucosa status and their microscopic structure can be good indicators of the response of the intestinal tract to active substances in feeds. Few reports have documented the effects of dietary polyphenols or related phenolics on localized intestinal growth and function in broiler chickens and their contribution to changes in performance. In a study in which chicks and rats were given diets high in freeze-dried tannins 
extracted from fava beans (Vicia faba), Ortiz et al. (1994) found histological lesions in the ileum, suggesting a loss in absorptive capacity. Results obtained by Sell et al. (1985), using high and low tannin sorghum in rats and laying hens, revealed milder negative effects. Examination of the distal digestive tract under a light microscope showed normal cells.

The only effect appeared to be a mild reduction in crypt depth and intestinal wall thickness and an increase in mucus secretion in the intestinal tract. In the present study, villus height and crypt depth were reduced, particularly in the jejunum. It is assumed that increase of the villus height is paralleled with increasing digestive and absorptive function of the intestine as a result of increased absorptive surface area, expression of brush border enzymes, nutrient transport systems (Caspary, 1992), and an increased bodyweight gain (Zijlstra et al., 1996). Sehm et al. (2007) reported that the inclusion of red wine pomace had an inhibitory effect on the jejunum villi growth. In agreement with the current results, Laurent et al. (2005) observed a decrease in the size of the microvilli from the addition of GSE in human intestinal Caco-2 cells. Viveros et al. (2011) reported that inclusion of grape pomace concentrate (GPC) and GSE decrease villus height and crypt depth in broiler chickens. Intestinal cell proliferation occurs mainly in the crypts (Geyra \& Sklan, 2001). Thus, the large crypt suggests a high nutrient requirement for intestinal maintenance and reduced efficiency of the bird. In this view, the lower crypt depth as a result of fed GP can be considered as a beneficial way to decrease the cost of intestinal maintenance in birds.

In the present study, a decrease in villus height/crypt depth ratio in birds fed diets was also found. A lengthening of the villus and a short crypt can lead to better nutrient absorption, decreased secretion in the gastrointestinal tract, increased disease resistance, and greater overall performance. In this sense, the low villi height:crypt depth ratio could have caused poorer growth in GP-fed chicks. In contrast, an increase in this ratio inthe jejunum in birds fed GPC diets was reported by Viveros et al. (2011). Moreover, muscularis thickness was decreased in birds fed a GP diet. In contrast, Viveros et al. (2011) reported that muscularis thickness was increased in birds fed GPC and GSE diets. Inclusion of feed antibiotics in diets of chicken reportedly leads to decreased thickness of walls and reduced weight (Miles et al., 2006). Many in vitro studies have demonstrated the antimicrobial properties of polyphenols (Arunachalam et al., 2003). Improved intestinal morphology characteristics such as lower crypt depth and epithelial thickness could lead to increased feed utilization and improved performance. There have been few studies on the interaction of polyphenol compounds with intestinal microbiota in animal nutrition. Numerous in vitro studies (Papadopoulou et al., 2005; Ganan et al., 2009) have shown that flavonoids in grape by-products have the capacity to inhibit the growth of organisms such as Staphylococcus aureus, Escherichia coli, Candida albicans and Campylobacter. Likewise in vivo studies have shown that resveratrol has potential as an antibiotic alternative for reversing the adverse effects of weaning stress on the growth performance, immunity and microbial environment in E.coli and Salmonella-challenged piglets (Ahmed et al., 2013).

The inhibiting effect of polyphenolic compounds on bacteria could be because of mechanisms related to their capacity to adhere to cellular membranes, to interact with bacterial enzymes and to sequester metallic ions from the substrate (Scalbert, 1991; Cushnie \& Lamb, 2011). In the present experiment, the lactobacilli stimulant activity of GP in the cecum could be attributed to the composition and phenolic profile of theseby-products and could depend directly on extractable polyphenol contents. A possible explanation for the stimulatory effect of polyphenolic compounds on bacterial growth is that some microorganisms are able to use these compounds as nutritional substrates. In lactobacilli, these bacteria possess the ability to metabolize phenolic compounds supplying energy to cells and positively affecting the bacterial metabolism (Garcia-Ruiz et al., 2008). In agreement with the current results, Viveros et al. (2011) confirmed the antibacterial effect of polyphenols in GPC and GSEon certain intestinal bacteria. This effect differs depending on the segment analysed (ileum or caecum). The inclusion of these by-products in bird diets exerted an antimicrobial effect on Clostridium in the ileum, while in the caecum it was associated with an increase in populations such as Lactobacillus and Enterococcus.

Regarding histopathological examination, Iqbal et al. (2015) reported that no changes were observed in the livers and kidneys of birds fed low and medium levels of GP polyphenols in diets. Also, mild changes in the livers and kidneys of birds fed a diet with a high level of GP polyphenols suggested that even higher polyphenols levels were relatively nontoxic to birds (lqbal et al., 2015). However, Haseeb et al. (2011) reported protective effects of GSE against aluminium toxicity in rats. Similarly, Sun et al. (1999) reported alleviating effects of GP polyphenols on chronic ethanol-induced morphological changes in rats. The GSE was reported to have many other beneficial effects such as hepatoprotection (Hassan, 2012), and protection againstsilica-induced pulmonary fibrosis (Ali et al., 2008), and ethanol-induced oxidative damage and ulcer (Cuevas et al., 2011). In the present study, GP supplementation to chicken diets did not have a significant impact on biochemical parameters. Only AST and ALT activity were increased significantly in tannase supplementation groups compared with the control $(P<0.05)$. 
Injury to the liver results in the release of intracellular enzymes into the extracellular space (Kristensen, 1994). Increases in plasma levels of the liver function enzymes AST and ALT are well known diagnostic indicators of liver injury (Chiu et al., 2013). The activity of AST is currently considered a sensitive indicator of hepatocellular disease in avian species. The greater plasma AST concentration in the Trial 3 and ALT in the Trial 4 relative to the other treatment may suggest hepatocellular necrosis by polyphenol compounds, which causes an increase in permeability of the cell membrane, resulting in the release of transaminase in the bloodstream. In agreement with the current results, Lu et al. (2014) reported that plasma AST concentration in a high-oxidant diet with vitamin E level at NRC requirement of $10 \mathrm{IU} / \mathrm{kg}$ was greater on day 21 and 42 relative to the group that were fed standard control diet supplementation with vitamin $E$ level at NRC requirement of $10 \mathrm{IU} / \mathrm{kg}$. Khudiar \& Aldabaj (2015) reported that grape seed oil (GSO) supplementation could alleviate hepatic changes induced in adult male rabbits by sodium fluoride as reflected by normalization of the measured liver function markers suggesting its potential hepatoprotective effect. The natural antioxidant in GSO may be responsible for its antioxidant property and for protection of DNA damage (Hassan et al., 2014) and was claimed to be the mechanism of hepatoprotective activity of GSO. Degenerative changes in liver were reported on feeding high tannin sorghum to poultry. Sannamani (2002) reported significant pathological changes in most of the tissues (lungs, liver, kidney, heart, intestine and pancreas) of birds fed on a $100 \%$ red sorghum-based diet without supplemental methionine. Moreover,histopathological examination of the liver of chicks or rats fed on the diets containing tannin showed hydropic degeneration of hepatocytes (Ortiz et al., 1994). There was no significant effect of feeding diets on relative liver weights in broilers. These results are in agreement with the thoseof Brenes et al. (2008), who reported that the inclusion of graded concentrations of GPC did not affect the relative liver and spleen weight.

Many investigators have demonstrated the efficacy of grape seed proanthocyanidins and grape juice as an inhibitor of lipid peroxidation and as a powerful free radical scavenger in vitro and in vivo (Dani et al., 2008; Khalifa et al., 2011; Naguib, 2011) in addition to its hepatoprotective effect (Hassan \& Al-Rawi, 2013). Thus it was suggested that the active component of grapes protect the hepatocytes from liver damage and subsequent leakage of enzymes into the circulation, and may have a curative effect against elevated transaminases (Ahmed \& Fatani, 2007; Al-Attar, 2015). Thus, likemany plant extracts, grape polyphenols have been shown to play a double-edged role in regulating the inflammatory system of the host. Caution in dosage should be taken carefully to avoid switching from beneficial effects to adverse ones. Blood proteins are important complementary constituents in the diagnosis of hepatic disease, although determination of these proteins seldom leads to diagnosis, althoughit helps to evaluate the nature, severity and progress of disease (Lumeij, 2008). Besides, GSE causes inhibition of gluconeogenesis and prevents catabolism of protein and its conversion to glucose (Bujanda et al., 2006. This may lead to increased levels of total polyphenol concentration in serum. Previous works found that GSE prevents oxidative injury (Puiggros et al.,2005), modulates glucose haemostatic (Montagut et al., 2010), and has an insulin-mimetic effect on adiposities and adipose tissue (Pinent et al., 2004). GSE, a well-known dietary supplement, (Weber et al., 2007), with its proanthocyanidins, possesses insulinomimetic properties (Decorde et al., 2009) by stimulating glucose uptake in insulin-sensitive cell lines, and decreases hyperglycaemia in streptozotocin diabetic rats (Pinent et al., 2004). Polyphenols are known to inhibit gut glucose absorption and peripheral tissue glucose uptake by glucose transporter (Pandy \& Rizvi, 2009), protect pancreatic islets cells, and inhibit insulin resistance (Zunino et al., 2007; Meydani \& Hasn, 2010), while flavonoids possess antidiabetogenic activity attributed to increased pancreatic secretion and insulin release from beta cells (Sharma et al., 2008; Sridhar et al., 2005).

\section{Conclusion}

The results presented in this study showed that increasing the concentration of GP up to 10 percent did not impair the performance and carcass characteristics of broiler chickens. The addition of GP to the chicken diets could increase cellular and humoral immune responses. The inclusion of tannase in diets containing GP increased the bioavailability and amount of total polyphenol released in the intestine and improved the antioxidant status of broilers. Based on the results of the present study, it can be stated that dietary polyphenol-rich grape products were effective in increasing the caecal populations of beneficial bacteria in the cecum.Crypt depth and epithelial thickness of chicken duodenum and the villus height and crypt depth were significantly reduced in the jejunum. These facts may have an important influence on the physiology and biochemistry of the gut. To optimize health benefits and minimize possible negative effects, more studies are needed to establish appropriate dosages of grape polyphenols and their bioavailability. 


\section{Acknowledgements}

The authors are grateful to Mohaghegh ArdabiliUniversity of Ardabil, Iran, for providing the experimental facilities and financial support for this experiment. We are also grateful to Kikkoman Food Products Co. (Japan) for gifting tannase enzyme.

\section{Authors' Contributions}

SKE and BN were in charge of the experimental design, implementation and writing the manuscript. All authors participated in interpreting and reviewing the results of the study.

\section{Conflict of Interest Declaration}

There are no conflicts of interest.

\section{References}

Abarghuei, M.J., Rouzbehan, Y. \& Alipour, D., 2010. The influence of the grape pomace on the ruminal parameters of sheep. Livest. Sci. 132, 73-79.

Acamovic, T. \& Brooker, J.D., 2005. Biochemistry of plant secondary metabolites and their effects in animals. Proc. Nutr. Soc. 64, 403-412.

Ahmed, A.E. \& Fatani, A.J., 2007. Protective effect of grape seeds proanthocyanidins against naphthalene-induced hepatotoxicity in rats. Sau. Pharmol. J. 15, 38-47.

Ahmed, S.T., Hossain, M.E., Kim, G.M., Hwang, J.A., Ji,H. \& Yang, C.J., 2013. Effects of resveratrol and essential oils on growth performance, immunityand microbial shedding in challenged piglets. Asian-Australs. J. Anim. Sci. 26, 683-690.

Akter, S., Khan, M., Jahan, M., Karim, M. \& Islam, M., 2006. Histomorphological study of the lymphoid tissues of broiler chickens. Bangla. J. Vet. Med. 4, 87-92.

Al-Attar, A.M., 2015. Effect of grape seed oil on diazinon induced physiological and histopathological alterations in rats. Sau. J. Biol. Sci. 22, 284-292.

Ali, A.H., Nazari, Z. \& Samei, M.A., 2008. Comparative study of grape seed extract and vitamin E effects on silicainduced pulmonary fibrosis in rats. Pul. Pharmacol. Thera. 21, 668-674.

AOAC, 2000. Official methods of analysis. 17thed. Association of Official Analytical Chemists, Arlington, VA.

Aoki, K., Shinke, R. \& Nishira, H., 1976. Purification and some properties of yeast tannase. Agri. Biolo. Chem. 40, 79-85.

Arunachalam, M., Raj, M.M., Mohan, N. \& Mahadevan, A., 2003. Biodegradation of catechin. Proc. Indian Natl. Sci. Acad. 69, 353-370.

Aviagen, 2014. Ross 308 broiler: Nutrition specification. Ross Breeders Limited, Newbridge, Midlothian, Scotland, UK.

Bajpai, B. \& Patil, S., 1996. Tannin acyl hydrolase (EC 3.1.1.20) activity of Aspergillus, Penicillium, Fusarium and Trichoderma. Worl. J. Microbiol. Biotechnol. 12, 217-220.

Brenes, A., Viveros, A., Goni, I., Centeno, C., Sayago-Ayerdi, S.G., Arija, I. \& Saura-Calixto, F., 2008. Effect of grape pomace concentrate and vitamin $\mathrm{E}$ on digestibility of polyphenols and antioxidant activity in chickens. Poult. Sci. 87, 307-316.

Bujanda, L., Barcina, M.G., Juan, V.G., Bidaurrazaga, J., Luco, M.F., Stampa, M.G., Larzabal, M., Hijona, E., Sarasqueta, C., Elizondo, M.E. \& Arenas, J.I., 2006. Effect of resveratrol on alcohol-induced mortality and liver lesions in mice. BioMed. Cent. Gastro, 6, 35.

Caspary, W.F., 1992. Physiology and pathophysiology of intestinalabsorption. Amer. J. Clini. Nutri. 55, 299-308.

Chamorro, S., Viveros, A., Alvárez, I., Vega, E. \& Brenes, A., 2012. Changes in polyphenol and polysaccharide content of grape seed extract and grape pomace after enzymatic treatment. Food Chem. 133, 308-314.

Chamorro, S., Viveros, A., Centeno, C., Romero, C., Arija,I. \& Brenes, A., 2013. Effects of dietary grape seed extract on growth performance,amino acid digestibility and plasma lipids and mineral content in broiler chicks. Animal 7, $555-561$

Chamorro, S., Viveros, A., Rebolé, A., Rica, A., Arija, B.D. \& Brenes, A.A., 2015. Influence of dietary enzyme addition on polyphenol utilization and meat lipid oxidation of chicks fed grape pomace. Food Res. Int. 73, 197-203.

Chiu, H.F., Chen, T.Y, Tzeng, Y.T. \& Wang, C.K., 2013. Improvement of liver function in humans using a mixture of schisandra fruit extract and sesamin. Phyto. Res. 27, 368-373.

Corrier, D.E. \& DeLoach, J.R., 1990. Evaluation of cell-mediated, cutaneous basophil hypersensitivity in young chickens by an interdigital skin test. Poult. Sci. 69, 403-408.

Cushnie, T.P. \& Lamb, A.J., 2011. Recent advances in understanding the antibacterial properties of flavonoids. Int. J. Antimicro. Ag. 38, 99-107.

Cuevas, V.M., Calzado, Y.R., Guerra, Y.P., Year, A.O., Despaigne, S.J., Ferreiro, R.M. \& Quintana, D.C., 2011. Effects of grape seed extract, vitamin $\mathrm{C}$, and vitamin $\mathrm{E}$ on ethanol and aspirin induced ulcers. Adv. Pharmacol. Sci. 18, 120-137.

Dani, C., Oliboni, L.S., Pasquali, M.A.B., Oliveira, M.R., Umezu, F.M., Salvador, M., Moreira, J.C.F. \& Henriques, A.P., 2008. Intake of purple grape juice as a hepatoprotective agent in wistar rats. J. Med. Food .11, 127-132.

Decorde, K., Teissedre, P.L., Sutra, T., Ventura, E., Cristol, J.P. \& Rouanet, J.M., 2009. Grape-seed procyanidins prevent lowgrade inflammation by modulating cytokine expression in rats fed a high-fat diet. Molc. Nutri. Food Res. 53, 659-666.

Deschamps, A., Otuk, G. \& Lebeault, J., 1983. Production of tannase and degradation of chestnut tannin by bacteria. J. Fermen. Technol. 61, 55-59.

FAO, 2013. STAT-FAO Statistical database. Available at http://faostat3. fao. org. 
Foti, M., Piatelli, M., Amico, V. \& Ruberto, G., 1994. Antioxidant activity of phenolic meroditerpenoids from marine algae. J. Photochem. Photobiol. 26, 159-164.

Ganan, M., Martinez-Rodriguez, A.J. \& Carrascosa, A.V., 2009. Antimicrobial activity of phenolic compounds of wines against Campylobacter jejuni. Food Cont. 20, 739-742.

Garcia-Pena, I., Augur, C. \& Favela-Torres, E., 1999. Purificacio' n parcial de tanasa producida por Aspergillus niger en fermentacion en medio solido. En, Ediciones UAM-Iztapalapa. 247-261.

Garcia-Ruiz, A., Bartolome, B., Martinez-Rodriguez, A.J., Puello, E., Martin-Alvarez, P.J. \& Moreno-Arribas, M.V., 2008. Potential of phenolic compounds for controlling lactic acid bacteria growth in wine. Food Cont. 19, 835-841.

Georgiev, V., Ananga, A. \& Tsolova, V., 2014. Recent advances and uses of grape flavonoids as nutraceuticals. Nutri. 6 , 391-415.

Geyra, A., Uni,Z. \& Sklan, D., 2001. Enterocyte dynamics and mucosal development in the post hatch chick. Poult. Sci. $80,776-782$.

Gladine, C., Morand, C., Rock, E., Bauchart, D. \& Durand, D., 2007. Plant extracts rich in polyphenols (PERP) are efficient antioxidants to prevent lipoperoxidation in plasma lipids from animals fed $n-3$ PUFA supplemented diets. Anim. Feed Sci.Technol. 136, 281-296.

Goni, I., Brenes, A., Centeno, C., Viveros, A., Saura-Calixto, A., Rebole, I. \& Arija, R., 2007. Effect of dietary grape pomace and vitamin $\mathrm{E}$ on growth performance, nutrient digestibility, and susceptibility to meat lipid oxidation in chickens. Poult. Sci. 86, 508-516.

Gonthier, M.P., Cheynier, V., Donovan, J.L., Manach, C., Morand, C. \& Mila, I., 2003. Microbial aromatic acid metabolites formed in the gut account for a major fraction of the polyphenols excreted in urine of rats fed red wine polyphenols. J. Nutri. 133, 461-467.

Hajati, H., Hassanabadi, A., Golian, A., Nassiri-Moghaddam, H. \& Nassiri, M.R., 2015. The effect of grape seed extract and vitamin $\mathrm{C}$ feed supplementation on some blood parameters and HSP70 gene expression of broiler chickens suffering from chronic heat stress. Italian J. Anim. Sci. 14, 3273.

Haseeb, M.M., Fahad, A., Hizab, A. \& Hussain,Y.A., 2011. A histopathologic study of the protective effect of grape seed extract against experimental aluminum toxicosis in male rats. Bas. Appl. Sci. 12, 283-295.

Hassan, H.A. \& Al-Rawi, M.M., 2013. Grape seeds proanthocyanidin extract as a hepatic-reno-protective agent against gibberellic acid induced oxidative stress and cellular alteration. Cytotechnol. 65, 567-576.

Hassan, H.A., Edrees, G.M., EL-Gamel, E.M. \& EL-Sayed, E.A., 2014. Amelioration of cisplatin induced nephrotoxicity by grape seed extract and fish oil is mediated by oxidative stress and DNA damage. Cytotechnol. 66, 419-429.

Hassan, H.M.M., 2012. Hepatoprotective effect of red grape seed extracts against ethanol-induced cytotoxicity. Glo. J. Biotechnol. Biochem. 7, 30-37.

Hashemi, S.R., Zulkifli, I., Davoodi, H., Zunita, Z. \& Ebrahimi, M., 2012. Growth performance, intestinal microflora,plasma fatty acid profile in broiler chickens fed herbal plants (Euphorbia hirta) and mix of acidifies. Anim. Feed Sci. Technol. 178, 167-174.

Hughes, R.J., Brooker, J.D. \& Smyl, C., 2005. Growth rate of broiler chickens given condensed tannins extracted from grape seed. Aust. Poult. Sci. Symp. Poultry Research Foundation, University of Sidney, Sidney, Australia, 56-68.

Iqbal, Z., Kamran, Z., Sultan, J.I., Ali, A., Ahmad, S., Shahzad, M.I., Ahsan, U. \& Ashraf Sand Sohail, M.U., 2015. Replacement effect of vitamin E with grape polyphenols on antioxidant status, immune, and organs histopathological responses in broilers from 1- to 35-d age. J. Appl. Poult. Res. 24, 127-134.

Jin, L.Z., Ho, Y.W., Abdullah, N. \& Jalaludin, S., 1998. Growth performance, intestinal microbial populations, and serum cholesterol of broilers fed diets containing Lactobacillus cultures. Poult. Sci. 77, 1259-1265.

Kara,K., Kocaoglu-Guclu, B., Baytok, E. \& Senturk, M., 2015. Effects of grape pomace supplementation to laying hen diet on performance, egg quality, egg lipid peroxidation and some biochemical parameters. J. Appli. Anim. Res. 44, 303-310.

Kawakubo, J., Nishira, H., Aoki, K. \& Shinke, R., 1991. Screening for gallic acid producing microorganisms and their culture conditions. Agri. Biolo. Chem. 55, 857-877.

Khalifa, F.K., Khalil, F.A., Barakat, H.A. \& Hassan, M.M., 2011.Protective role of wheat germ and grape seed oil in chlorpyrifos-induced oxidative stress, biochemical and histological alterations in liver of rats. Austr. J. Bas. Appli. Sci. 5, 54-66.

Khudiar, K,K. \& Aldabaj, A.M.A., 2015. Effect of grape seed oil on hepatic function in adult male rabbits treated with sodium fluoride (Partll). Adv. Anim. Vet. Sci. 3, 550-558.

Konowalchuk, J. \& Speirs, J.I., 2009. Virus inactivation by grapes and wines. Appli. Environ. Microbiol. 32, 757-763.

Kristensen, S.R., 1994. Mechanisms of cell damage and enzyme release. Denmark Medical Bulletin . 41,423-433.

Lafay, S., \& Gil-Izquierdo, A., 2008. Bioavailability of phenolic acids. Phytochem. Revi. 7, 301-311.

Lau, D.W. \& King, A.J., 2003. Pre- and post-mortem use of grape seed extract in dark poultry meat to inhibit development of thiobarbituric acid reactive substances. J. Agri. Food Chem. 51,1602-1607.

Laurent, C., Besancon, P. \& Caporiccio, B., 2005. Ethanol and polyphenolic free wine matrix stimulate the differentiation of human intestinal Caco-2 cells. Influence of their association with a procyanidin-rich grape seed extract. J. Agric. Food Chem. 53, 5541-5548.

Lekha, P. \& Lonsane, B., 1994. Comparative titres, location and properties of tannin acyl hydrolase produced by Aspergillus niger PKL 104 in solid-state, liquid surface and submerged fermentations. Pro. Biochem. 29, 497-503.

Lekha, P. \& Lonsane, K., 1997. Production and application of tannin acyl hydrolase: State of the art. Adv. Appli. Microbiol. 44, 215-260.

Leshchinsky, T.V. \& Klasing, K.C., 2001. Relationship between the level of dietary vitamin E and the immune response of broiler chickens. Poult. Sci. 80, 1590-1599. 
Lien, T.F., Yeh, H.S. \& Su, W.T., 2008. Effect of adding extracted hesperetin, naringenin and pectin on egg cholesterol, serum traits and antioxidant activity in laying hens. Arch. Anim. Nutri. 62, 33-43.

Libuchi, S. \& Monida Yand Yamada, K., 1967. Studies on tannin acylhydrolase of microorganisms Part III. Purification of enzyme and some properties of it. Agri. Biological Chem. 32, 803-809.

Lu,T., Harper, A.F., Zhao, J., Corl, B.A., LeRoith, T. \& Dal, R.A., 2014. Effects of a dietary antioxidant blend and vitamin $E$ on fatty acid profile, liver function, and inflammatory response in broiler chickens fed a diet high in oxidants. Poult. Sci. 93, 1658-1666.

Lumeij, J.T., 2008. Avian clinical biochemistry. Clinical biochemistry of domestic animals. 6th ed.Academic Press, San Diego, 839-872.

Meydani, M. \& Hasn, S.T., 2010. Dietary polyphenols and obesity. Nutrients . 2, 737-751.

Miles, R.D., Butcher, G.D., Henry, P.R. \& Littell, R.C., 2006. Effect of antibiotic growth promoters on broiler performance, intestinal growth parameters and qualitative morphology. Poult. Sci. 85, 476-485.

Monagas, M., Urpi-Sarda, M., Sánchez-Patán, F., Llorach, R., Garrido, I. \& Gómez-Cordovés, C., 2010. Insights into the metabolism and microbial biotransformation of dietary flavan-3-ols and the bioactivity of their metabolites. Food \& Function. 1, 233-253.

Montagut, G., Blade, C., Blay, M., FernandezLarrea, J., Pujadas, G., Salvado, M.J., Arola, L., Pinent, M. \& Ardevol, A., 2010. Effects of a grape seed procyanidin extract (GSPE) on insulin resistance. J. Nutri. Biochem. 21, 961-967.

Naguib, N.I., 2011. Grape seed oil extract protects against radiation-induced oxidative damage in rats eye. Iso. Rad. Re. $43,1255-1264$

Ortiz, L.T., Alzueta, C., Trevino, J. \& Castano, M., 1994. Effects of faba bean tannins on the growth and histological structure of the intestinal tract and liver of chicks and rats. Briti. Poult. Sci. 35, 743-754.

Ozgan, A., 2008. Use of grape seed oil in functional egg production (MSc thesis). University of Cukurova, Adana, Turkey.

Pandy, K.B. \& Rizvi, S.I., 2009. Current understanding of dietary polyphenols and their role in health and disease. Curr. Nutri. FoodSci. 5, 249-263.

Papadopoulou, C., Soulti, K. \& Roussis, G., 2005. Potential antimicrobialactivity of red and white wine phenolic extracts against strains of Staphylococcus aureus, Escherichia coli and Candida albicans. Food Tech. Biotechnol. 43, 4146.

Pinent, M., Blay, M., Blade, M.C., Salvado, M.J., Arola, L. \& Ardevol, A., 2004. Grape seed-derived procyanidins have an antihyperglycemic effect in streptozotocin induced diabetic rats and insulinomimetic activity in insulin-sensitive cell lines. Endocrinol. 145, 4985-4990.

Placer, Z.A., Cushman, L.L. \& Johnson, B.C., 1966. Estimation of product of lipid peroxidation (malondialdehyde) in biochemical systems. Anal. Biochem. 16, 359-364.

Puiggros, F., Llòpiz, N., Ardévol, A., Bladé, C., Arola, L. \& Salvadó, M.J., 2005. Grape seed procyanidins prevent oxidative injury by modulating the expressionof antioxidant enzyme systems. J. Agri. Food Chem. 53, 6080-6086.

Qureshi, M.A. \& Havanstein, G.B., 1994. A comparison of the immune performance of a 1991 commercial broiler with a 1957 randombred strain when fed 'typical' 1957 and 1991 broiler diets. Poult. Sci. 73,1805-1812.

Rahimi, S., Teymouri Zadeh, Z., Karimi Torshizi, M.A., Omidbaigi, R. \& Rokni, H., 2011. Effect of the three herbal extracts on growth performance, immune system, blood factors and intestinal selected bacterial population in broiler chickens. J. Agri. Sci. Technol.13, 527-539.

Rajakumar, G. \& Nandy, S., 1983. Isolation, purification and some properties of Penicillium chrysogenum tannase. Appli. Environ. Microbiol. 46, 525-527.

Sannamani, P.G., 2002. Feeding value of sorghum grains vis-à-vis yellow maize for broiler chicks. M.V.Sc. thesis. Deemed University, IVRI, Izatnagar, India.

SAS, 2001. Statistical analysis systems. STATUser'sguide. Statistics version 9.1.

Scalbert, A., 1991. Antimicrobial properties of tannins. Phytochem. 30, 3875-3883.

Sehm, J., Lindermayer, H., Dummer, C., Treutter, D. \& Pfaffl, M.W., 2007. The influence of polyphenol rich apple pomace orred-wine pomace diet on the gut morphology in weaning piglets. J. Anim. Physiol. Anim. Nutri. 91, 289296.

Sell, D.R., Reed, W.M., Chrisman, C.L. \& Rogler, J.C., 1985. Mucin excretion and morphology of the intestinal tract as influenced by sorghum tannins. Nutri. Report Int. 31, 1369-1374.

Seven, T.P., Seven, I., Yilmaz, M.M. \& Ugsims, E.K., 2008. The effects of Turkish propolis on growth and carcass characteristics in broilers under heat stress. Anim. Feed Sci. Technol. 146, 137-148.

Sharma, S.B., Balomajumder, C. \& Roy, C., 2008. Hypoglycemic and hypolipidemic effects of flavonoids rich from Eugenia jambolana on streptozotocin induced diabetic rats. J. Ethnopharmacol. 85, 201-206.

Singleton, V.L. \& Rossi, J.A., 1965. Colorimetry of total phenolics with phosphomolybdic phosphotungstic acid reagents. Amer. J. Enol. Viticul. 16,144-158.

Skene, I. \& Brooker, J., 1995. Characterization of tannin acylhydrolase activity in the ruminal bacterium Selenomonas ruminantium. Anaerobe 1, 321-327.

Sridhar, S.B., Sheetal, U.D., Pai, M.R.S.M. \& Shastri, M.S., 2005. Preclinical evaluation of the antidiabetic effect of Eugenia jambolana seed powder in streptozotocin diabetic rats. Braz. J. Med. Biol. Res. 38, 463-468.

Sun, G.Y., Xia, J., Xu, J., Allenbrand, B., Simonyi, A., Rudeen, P.K. \& Sun, A.Y., 1999. Dietary supplementation of grape polyphenols to rats ameliorates chronic ethanolinduced changes in hepatic morphology without altering changes in hepatic lipids. J. Nutri. 129, 1814-1819.

Tepe, B., Daferera, D., Sokmen, M., Polission, M. \& Sokmen, A., 2004. In vitro antimicrobial and antioxidants activities of essential oils and various extracts of Thymus eigii. J. Agri. Food Chem. 52, 1132-1137. 
Viveros, A., Chamorro, S., Pizarro, M., Arija, I., Centeno, C. \& Brenes, A., 2011. Effects of dietary polyphenol-rich grape products on intestinal microflora and gut morphology in broiler chicks. Poult. Sci. 90, 566-578.

Weber, H.A., Hodges, A.E., Guthrie, J.R., Brien, B.M., Robaugh, D., Clark, A.P., Harris, R.K., Algaier, J.W. \& Smith, C.S., 2007. Comparison of proanthocyanidins in commercial antioxidants: Grape seed and pine bark extracts. J. Agri. Food Chem. 55, 148-156.

Xia, E.Q., Deng, G.F., Ya-Jun, K.,Guo, Y.J. \& Hua-BinLi, H.B., 2010. Biological activities of polyphenols from grapes. Inter. J. Molc. Sci.11, 622-646.

Yang, C.S., Wang, X., Lu, G. \& Picinich, S.C., 2009. Cancer antioxidant redox signaling. Life Sci. 7, $1704-1714$.

Yilmaz, Y. \& Toledo, R.T., 2004. Major flavonoids in grape seeds and skins: Antioxidant capacity of catechin, epicatechin, and gallic acid. J. Agri. Food Chem. 52, 255-260.

Zhu, M., Phillipson, D., Greengrass, P.M., Bowery, N.E. \& Cai, Y., 1997. Plant polyphenols: Biologically active compounds or non-selective binders to proteins. Phytomed. 3, 281-285.

Zijlstra, R.T., Whang, K.Y., Easter, R.A. \& Odle, J., 1996. Effectof feeding a milk replacer to earlyweaned pigs on growth, body composition, and small intestinal morphology, compared with suckled littermates. J. Anim. Sci. 74, 29482959.

Zunino, S.J., Storms, D.H. \& Stephenson, C.B., 2007. Diets rich in polyphenols and vitamin A inhibit the development of type I autoimmune diabetes in non-obese diabetic mice. J. Nutr. 137, 1216-1221. 